\title{
ORNLTM-13375
}

\author{
RECEIVED \\ MAR 201997 \\ OSTI
}

\section{Project Management Plan for the Objective Supply Capability Adaptive Redesign (OSCAR) Project}

\author{
K. A. Rasch \\ R. W. Reid
}

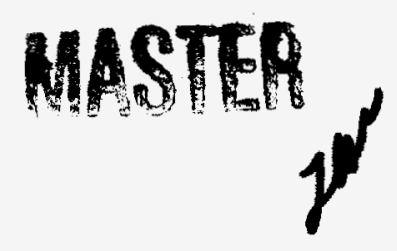

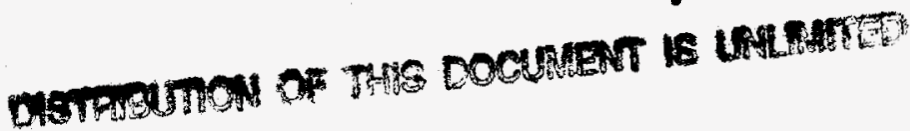

WNACED ANO OPERATEO BY

LOCKHEEO WARTW ENERCY RESEARG CORPORATON FOR THE UNTEO STATES

DEPARTMENT OF ENARG 
This report has been reproduced directly from the best available copy.

Available to DOE and DOE contractors from the Office of Scientific and Technical

Information, P.O.Box 62, Oak Ridge, TN 37831; prices available from (423) 576-8401, FTS 626-8401.

Available to the public from the National Technical Information Service, U.S. Department

of Commerce, 5285 Port Royal Rd., Springfield, VA 22161

This report was prepared a an account of work sponsored by an agency of the United States Govemment. Neither the United States Government nor any agency thereof, nor any of their employees, makes any warranty, express or implied, or assumes any legal liability or responsibility for the accuracy, completeness, or usefulness of any information, apparatus, product, or process disclosed, or represents that its use would not infringe privately owned rights. Reference herein to any specific commercial product, process, or service by trade name, trademark, manufacturer, or otherwise, does not necessarily constitute or imply its endorsement, recommendation, or favoring by the United Stales Government or any agency thereof. The view and opinions of authors expressed herein do not necessarily state or reflect those of the UnitedStatesGovernment or any agency thereof. 


\section{DISCLAIMER}

Portions of this document may be illegible electronic image products. Images are produced from the best available original document. 
Computational Physics and Engineering Division

\title{
PROJECT MANAGEMENT PLAN \\ FOR THE \\ OBJECTIVE SUPPLY CAPABILITY ADAPTIVE \\ REDESIGN (OSCAR) PROJECT
}

\author{
K. A. Rasch \\ R. W. Reid
}

Date Published: February 1997

\author{
Prepared by the \\ Oak Ridge National Laboratory \\ Oak Ridge, Tennessee 37831-6397 \\ Managed by \\ LOCKHEED MARTIN ENERGY RESEARCH CORP. \\ for the \\ U.S. DEPARTMENT OF ENERGY \\ under contract DE-AC05-96OR22464
}




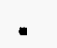

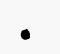


APPROVALS

The following signatures indicate acceptance of, concurrence with, and support of this Project Management Plan for the Objective Supply Capability Adaptive Redesign (OSCAR) Project.

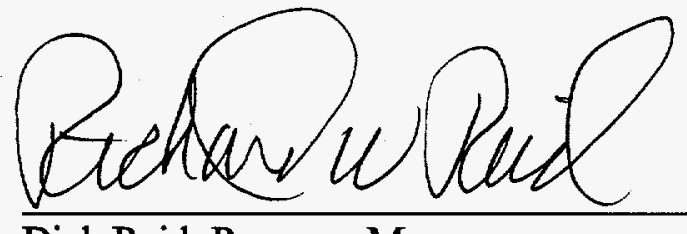

Dick Reid, Program Manager Oak Ridge National Laboratory
Date:

$1 / 27 / 9$

Date: $1 / 27 / 97$

Kevin Rasch, Project Manager Oak Ridge National Laboratory

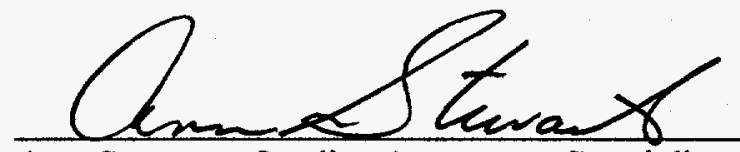

Ann Stewart, Quality Assurance Specialist Data Systems Research and Development
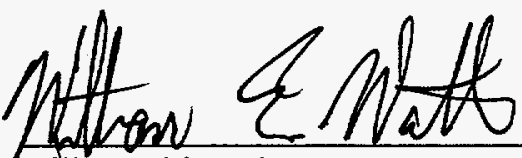

Bill Watkins, Sponsor Representative

Date: $22-27$

Date: $|-29-9\rangle$

National Guard Bureau

iii 
.

.

. 


\section{CONTENTS}

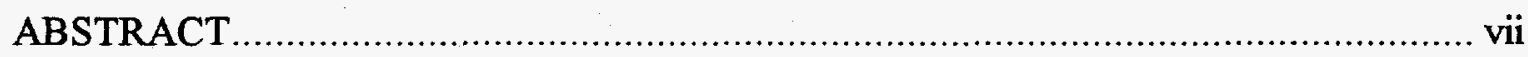

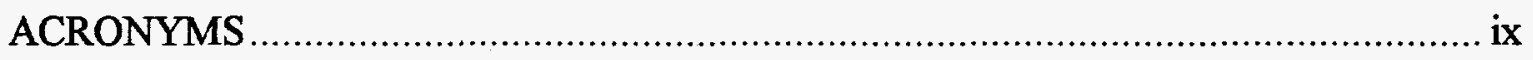

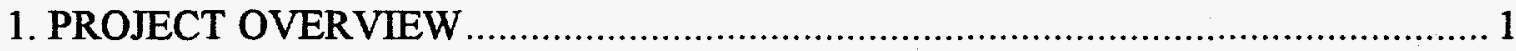

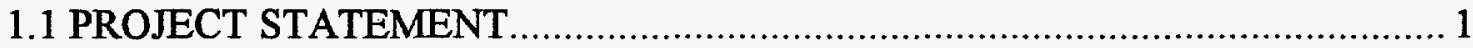

1.1.1 State OSC Gateway ....................................................................... 1

1.1.2 Excess Management Gateway ......................................................... 1

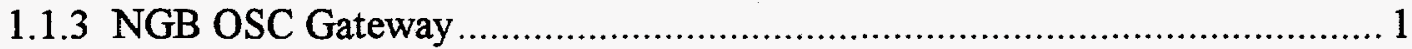

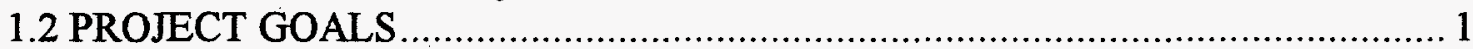

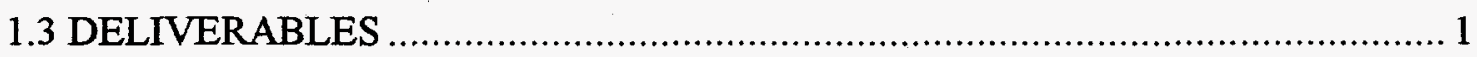

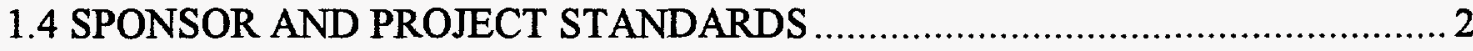

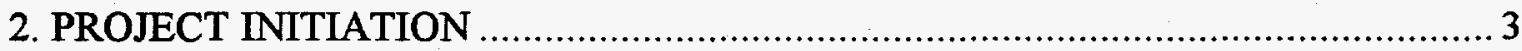

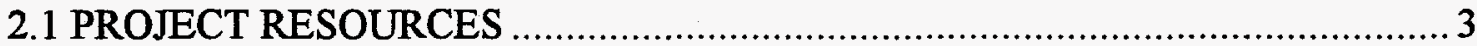

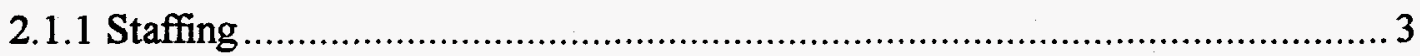

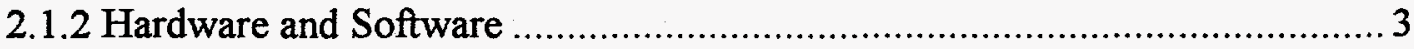

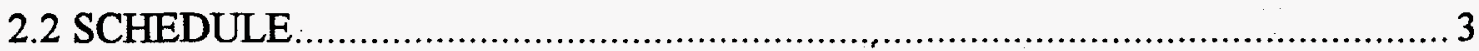

2.3 COST ESTIMATES............................................................................... 4

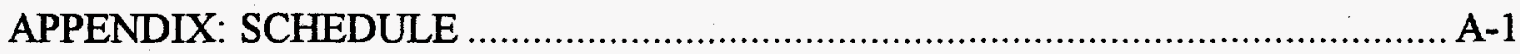




\begin{abstract}
This document establishes the project management plan for design and development of the Object Supply Capability Adaptive Redesign (OSCAR) Project. The purpose of the project management plan is to document the plans, goals, directions, commitments, approaches, and decisions that relate to guiding a project throughout its life cycle. Special attention is given to project goals, deliverables, sponsor and project standards, project resources, schedule, and cost estimates.
\end{abstract}




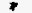




\section{ACRONYMS}

DOE U.S. Department of Energy

LMER Lockheed Martin Energy Research Corporation

NGB National Guard Bureau

ORNL Oak Ridge National Laboratory

OSC Objective Supply Capability

OSCAR Objective Supply Capability Adaptive Redesign

PMP project management plan 


\section{PROJECT OVERVIEW}

\subsection{PROJECT STATEMENT}

The Object Supply Capability Adaptive Redesign (OSCAR) system consists of three subsystems: the State Objective Supply Capability (OSC) Gateway, the Excess Management Gateway, and the National Guard Bureau (NGB) OSC Gateway.

\subsubsection{State OSC Gateway}

Each state will run the State OSC Gateway subsystem on a workstation at its site. This subsystem will control communications between each state and the other two systems (which will both be running on a workstation at the NGB site in Arlington, Virginia). It will also be responsible for converting input data from multiple National Guard systems into a common format.

NGB will develop this subsystem internally. The Oak Ridge National Laboratory will be responsible for ensuring that communication and interfaces between the gateways and the other subsystems are established and perform effectively.

\subsubsection{Excess Management Gateway}

The Excess Management Gateway subsystem will streamline management of excess equipment that affects a unit's readiness to go to war. This streamlining will be achieved by automating some of the tasks that asset managers currently perform manually.

\subsubsection{NGB OSC Gateway}

The NGB OSC Gateway subsystem will store information about excess supplies at National Guard units across the country. When a unit orders new supplies, this subsystem will determine whether the supplies are available as excess from another National Guard site. If so, it will effect a transfer of the supplies.

\subsection{PROJECT GOALS}

The overall goal of this project is to deliver software to NGB that will enable it to more effectively manage its excess supplies. Specific functional goals will be grouped into project phases. At the conclusion of each phase, a prototype software module will be installed and feedback will be solicited from NGB. This feedback will be used to refine the project requirements further.

\subsection{DELIVERABLES}

Deliverables fall into two categories-documentation and software. Documentation deliverables are as follows: 
- Quality Assurance Plan

- Project Management Plan

- Configuration Management Plan

- User Manual

Note that the User Manual will be written primarily by NGB personnel.

Software deliverables are grouped by phase in the following table. Note that deliverables in later phases may be changed by NGB to reflect knowledge gained from prototypes installed during the early phases.

\begin{tabular}{|l|l|}
\hline Phase & Software Deliverables \\
\hline I & OSCAR Excess Management Client version 1.0. \\
\hline & OSCAR Server version 1.0 (includes Excess Management Gateway). \\
\hline & \\
\hline II & OSCAR Excess Management Client version 2.0. \\
\hline & OSCAR Server version 2.0 (adds support for new Excess Management Client). \\
\hline & - \\
\hline III & OSCAR Server version 3.0 (adds NGB OSC Gateway). \\
\hline & \\
\hline IV & OSCAR Server version 4.0 (adds ARMIS support). \\
\hline
\end{tabular}

Note that all software deliverables after the second phase of the project must interface with the State OSC Gateway that NGB will develop internally.

\subsection{SPONSOR AND PROJECT STANDARDS}

Documentation and software development will follow requirements as defined by the U.S. Department of Energy (DOE) and Lockheed Martin Energy Research Corporation (LMER). Satisfying DOE and LMER standards will also satisfy NGB standards. 


\section{PROJECT INITIATION}

\subsection{PROJECT RESOURCES}

\subsubsection{Staffing}

The success of the project will depend on coordinating the efforts of Lockheed Martin personnel as well as personnel provided by NGB. For this reason, the following table includes the names of personnel from both organizations.

\begin{tabular}{|l|l|l|}
\hline Name & Organization & Primary Role \\
\hline Kevin Rasch & Lockheed Martin & $\begin{array}{l}\text { Project manager, software } \\
\text { developer }\end{array}$ \\
\hline Dick Reid & Lockheed Martin & Program manager \\
\hline Ann Stewart & Lockheed Martin & Quality assurance specialist \\
\hline Sgt. Tammy Snyder & Army National Guard & System administrator \\
\hline TBN & Army National Guard & State OSC Gateway developer \\
\hline CW3 Bobby Pelath & Army National Guard & Technical contact \\
\hline
\end{tabular}

\subsubsection{Hardware and Software}

The following platforms will be used for the development of OSCAR:

- Sun SPARCstation 20 running Solaris 2.4 and Informix Online 7.1

- Intel Pentium-based personal computer running Windows NT 4.0

The following software tools are anticipated for use in developing OSCAR:

- Informix Connect

- Informix ESQL/C

- Intersolv DataDirect ODBC driver for Informix

- SunSoft Visual Workshop C++

- Rogue Wave Tools+t.h

- Rogue Wave DBTools++.h

- Erwin/ERX

- Visual FoxPro

- Crystal Reports Professional

\subsection{SCHEDULE}

A schedule for the project is shown in Appendix A. This schedule will be updated periodically during the life of the project. 
As previously stated, OSCAR will be developed in phases. At the end of each phase, a prototype system will be installed and feedback will be solicited from NGB. This feedback will be used to refine the specifications and design of later phases. For this reason, the schedule does not yet include tasks after the second phase of the project.

\subsection{COST ESTIMATES}

Cost estimates for the project are summarized in the following table. These estimates include company overhead.

\begin{tabular}{|l|r|r|r|}
\hline Description & FY 1997 & FY 1998 & FY 1999 \\
\hline Labor & $\$ 200,000$ & $\$ 200,000$ & $\$ 100,000$ \\
\hline Travel & 20,000 & 20,000 & 10,000 \\
\hline Hardware/software & 30,000 & 10,000 & 10,000 \\
\hline DOE added factor (4.3\%) & 10,750 & 9,890 & 5,160 \\
\hline Total & $\$ 260,750$ & $\$ 239,890$ & $\$ 125,160$ \\
\hline
\end{tabular}




\section{APPENDIX: SCHEDULE}

\begin{tabular}{|c|c|c|c|c|}
\hline Task & Complete & Control & Projected & Remarks \\
\hline PHASE 1 & $22 \%$ & No & Tue 4/29/97 & \\
\hline Documentation-Quality Assurance Plan & $100 \%$ & Yes & Mon 12/30/96 & \\
\hline Documentation-Database Model & $100 \%$ & Yes & Mon 12/30/96 & \\
\hline Windows Program-Database Login & $95 \%$ & Yes & Thu $1 / 2 / 97$ & \\
\hline Windows Program-Menus & $80 \%$ & Yes & Mon $1 / 6 / 97$ & \\
\hline Windows Program-Catalog Data Import & $0 \%$ & No & Wed $1 / 8 / 97$ & \\
\hline Windows Program-Dodaac Data Import & $0 \%$ & No & Fri $1 / 10 / 97$ & \\
\hline Documentation-Project Management Plan & $90 \%$ & Yes & Fri 1/10/97 & \\
\hline Documentation-Configuration Control Plan & $90 \%$ & Yes & Fri $1 / 10 / 97$ & \\
\hline Windows Program-Auto Disposition Table Maintenance & $0 \%$ & Yes & Fri $1 / 24 / 97$ & \\
\hline Windows Program-Setup Table Maintenance & $0 \%$ & Yes & Mon $1 / 27 / 97$ & \\
\hline Windows Program-Priority Table Maintenance & $0 \%$ & Yes & Wed 1/29/97 & \\
\hline Windows Program-Ricc Table Maintenance & $0 \%$ & Yes & Tue $2 / 4 / 97$ & \\
\hline Windows Program-Condition Table Maintenance & $0 \%$ & Yes & Thu $2 / 6 / 97$ & \\
\hline Windows Program-SOS Table Maintenance & $0 \%$ & Yes & Mon 2/10/97 & \\
\hline Windows Program-User Table Maintenance & $0 \%$ & Yes & Wed $2 / 12 / 97$ & \\
\hline Windows Program-User/SOS Table Maintenance & $0 \%$ & Yes & Mon 2/17/97 & \\
\hline Windows Program-State Table Maintenance & $0 \%$ & Yes & Wed $2 / 19 / 97$ & \\
\hline Populate Database-Development Platform & $10 \%$ & Yes & Thu 2/20/97 & \\
\hline Windows Program-Manual Excess Management & $0 \%$ & Yes & Thu $2 / 27 / 97$ & \\
\hline Testing-Test Interactive Processes-Validation & $0 \%$ & Yes & Fri $2 / 28 / 97$ & Bobby in Oak Ridge for this \\
\hline Communications-Data Flow Input & $10 \%$ & No & Tue $3 / 4 / 97$ & \\
\hline Communications-Data Flow Output & $10 \%$ & No & Thu 3/6/97 & \\
\hline Testing-Test Communications from Customer & $0 \%$ & No & Fri 3/7/97 & Bobby in Oak Ridge for this \\
\hline Testing-Test Communications to Customer & $0 \%$ & No & Mon 3/10/97 & Bobby in Oak Ridge for this \\
\hline Timer Program-Framework & $0 \%$ & Yes & Mon 3/17/97 & \\
\hline Timer Program-Import Transactions from Customers & $0 \%$ & No & Wed 3/19/97 & \\
\hline Timer Program-Process Transactions from Customers & $0 \%$ & Yes & Wed $3 / 26 / 97$ & \\
\hline Timer Program-Send Transactions to Daas/Customers & $0 \%$ & No & Mon 3/31/97 & \\
\hline Timer Program-Scan Master-Handle days_archive & $0 \%$ & Yes & Tue 4/1/97 & \\
\hline Timer Program-Scan Master-Handle days_mgt_notify & $0 \%$ & Yes & Wed 4/2/97 & \\
\hline Excess Conference & $0 \%$ & No & Tue 4/8/97 & \\
\hline Timer Program-Scan Master-Handle days_auto_status & $0 \%$ & Yes & Wed 4/9/97 & \\
\hline
\end{tabular}


APPENDIX: SCHEDULE

\begin{tabular}{|c|c|c|c|c|}
\hline Task & Complete & Control & Projected. & Remarks \\
\hline Timer Program-Scan Master-Handle days_ftr_status & $0 \%$ & Yes & Thu $4 / 10 / 97$ & \\
\hline Timer Program-Scan Master-Handle days_ftm_create & $0 \%$ & Yes & Fri 4/11/97 & \\
\hline Timer Program-Scan Master-Handle days_ftm & $0 \%$ & Yes & Mon 4/14/97 & \\
\hline Testing-Test Interactive Processes-User & $0 \%$ & Yes & Tue $4 / 15 / 97$ & Harry in Oak Ridge for this \\
\hline Testing-Test Automated Processes & $0 \%$ & Yes & Wed $4 / 16 / 97$ & \\
\hline Quality Assurance Surveillance-Phase 1 & $0 \%$ & No & Thu 4/17/97 & \\
\hline Installation-Sun Hardware & $0 \%$ & Yes & Fri 4/18/97 & Kevin in Arlington for this \\
\hline Installation-Sun Database & $0 \%$ & Yes & Tue $4 / 22 / 97$ & Kevin in Arlington for this \\
\hline Installation-Sun Software/Setup Accounts & $0 \%$ & Yes & Wed 4/23/97 & Kevin in Arlington for this \\
\hline Installation-PC Software & $0 \%$ & Yes & Thu $4 / 24 / 97$ & Kevin in Arlington for this \\
\hline Training-Phase 1 & $0 \%$ & Yes & Mon 4/28/97 & Kevin in Arlington for this \\
\hline Populate Database-Production Platform & $0 \%$ & Yes & Tue $4 / 29 / 97$ & System Admin/Supervisor task \\
\hline Testing-Pilot States & $0 \%$ & No & Tue $4 / 29 / 97$ & Projected start date \\
\hline PHASE 2 & $0 \%$ & Yes & Thu 6/12/97 & \\
\hline Windows Program-Automated Excess Management & $0 \%$ & Yes & Tue $5 / 20 / 97$ & \\
\hline Windows Program-Reports & $0 \%$ & Yes & Wed 6/4/97 & \\
\hline Quality Assurance Surveillance-Phase 2 & $0 \%$ & No & Thu $6 / 5 / 97$ & \\
\hline Testing-Phase 2 Enhancements & $0 \%$ & Yes & Mon 6/9/97 & \\
\hline Installation-Phase 2 Enhancements & $0 \%$ & Yes & Wed $6 / 11 / 97$ & Kevin in Arlington for this \\
\hline Training-Phase 2 & $0 \%$ & Yes & Thu $6 / 12 / 97$ & Kevin in Arlington for this \\
\hline
\end{tabular}

